\title{
CORRELATION OF SERUM MAGNESIUM WITH DYSLIPIDEMIA IN MAINTENANCE HEMODIALYSIS PATIENTS
}

\author{
Hamid Nasri' $^{1}$, Azar Baradaran ${ }^{2}$ \\ Shahrekord University of Medical Sciences, Shahrekord, Iran: Hajar Medical, Educational and Therapeutic Center, \\ Section of Hemodialysis ${ }^{1}$; Hospital Bou-Ali, Damavand St.Tehran, Iran: Center of Research and Reference Laboratory of \\ $\mathrm{Iran}^{2}$
}

Summary: One of the factors involved in accelerated atherosclerosis in hemodialysis patients is dyslipidemia. In this study we considered factors involved in intensification of dyslipidemia in hemodialysis patients. This study was done on 36 maintenance hemodialysis patients. Serum lipoprotein (a), Triglyceride, Cholesterol, HDL-C,LDL-C and also serum Intact parathormone(iPTH), Calcium, Phosphorus, Magnesium were measured. In statistical analysis there was not any correlation between serum lipids and iPTH. There was not correlation between serum calcium with serum lipids $(p>0.05)$. There was not correlation between CaxP product with serum lipids $(\mathrm{p}>0.05)$. There was a positive correlation between serum Magnesium and Lipoprotein(a) $(\mathrm{P}<0.05)$ and also positive correlation between serum magnesium with triglyceride level $(\mathrm{P}<0.05)$ was seen too. Magnesium doesn't increase the lipoprotein synthesis. It may involve in the regulation of some enzymes responsible for lipoprotein synthesis. Correlation of serum magnesium with serum triglycerides can be due to changes in hepatic triglyceride metabolism. Lipoprotein(a) is a non traditional factor of premature atherosclerosis, its association with serum magnesium needs more attention in hemodialysis patients.

Key words: Magnesium; Hemodialysis, Dyslipidemia; Parathormone

\section{Introduction}

Hemodialysis patients are characterized by a number of biochemical abnormalities including hyperlipidemia. The importance of cardiovascular illness as the cause of death in hemodialysis patients, make it imperative to consider the risk factors involved (2). Hyperlipidemia has been incriminated as a risk factor of atherosclerotic vascular disease in dialyzed patients (6). Hemodialysis is associated with hypertriglyceridemia without cholesterol accumulation. The principle other dyslipidemias consisting of high serum lipoprotein (a) levels and low serum high density lipoprotein, whereas plasma low density lipoprotein (LDL) cholestrol is usually not elevated $(2,6,7)$. The cause of hypertriglyceridemia is an increased production of Apo $\mathrm{B}$ protein and a marked decrease in the metabolism of VLDL, Primarily as a result of decreased endothelial cell delipidation of VLDL (6).Magnesium $(\mathrm{Mg})$ retention can be a problem in patients on maintenance hemodialysis. Magnesium deficiency has a possible role in the perturbation of lipid metabolism in the non-uremic population. Furthermore other data showed that there is a correlation between dyslipidemia and high magnesium level in hemodialysis patients (11), but data are scanty and we therefore sought to consider the association of serum Magnesium and the lipid profiles in patients under maintenance hemodialysis treatment due to end-stage renal failure disease.

\section{Materials and methods}

This study is descriptive-analytic that was carried- out on thirty-six patients under regular hemodialysis due to end-stage renal failure. Since 3 years ago all of the patients hemodialyzed with polysulfone membrane hollow fibers. Patients undergoing thrice or twice weekly hemodialysis. The duration of each hemodialysis session is four hour. The magnesium concentration in the dialysate fluid is $1 \mathrm{mmol} / \mathrm{L}$. Factors serves as exclusion criteria were antilipid drug taking and active or chronic infection.For patients' plasma cholesterol (Chol) Triglyceride ( $\mathrm{Tg}$ ), High- density lipoproteincholestrol (HDL-C), Lipoprotein (a) [Lp(a)] and Intact parathormon (iPTH), serum Magnesium (Mg), Calcium (Ca), Phosphorus(P) were measured. Low-density lipoprotein-cholestrol (LDL-C) was calculated by friedewald's formula (3). Lipoprotein (a) measured by enzyme immunoassay (ELISA) with Immuno-biological laboratories (IBL) kit of Germany, other lipids were measured by standard kits, iPTH was measured by RIA with DSL-8000 
Tab. 1: The results of laboratory data.

\begin{tabular}{|l|c|c|c|}
\hline Variable & Maximum & Mininimum & Mean \pm SD \\
\hline $\mathrm{LP}(\mathrm{a}) \mu \mathrm{mol} / \mathrm{L}$ & 3.4 & 0.32 & $1.3 \pm 0.70$ \\
\hline $\mathrm{Tg} \mathrm{mmol} / \mathrm{L}$ & 3.4 & 0.45 & $1.53 \pm 0.75$ \\
\hline Chol mmol/L & 5.8 & 2.6 & $3.98 \pm 0.8$ \\
\hline $\mathrm{HDL}-\mathrm{C} \mathrm{mmol} / \mathrm{L}$ & 1.3 & 0.47 & $0.74 \pm 0.26$ \\
\hline $\mathrm{LDL}-\mathrm{C} \mathrm{mmol} / \mathrm{L}$ & 4.14 & 0.26 & $2.3 \pm 1$ \\
\hline $\mathrm{iPTH} \mathrm{ng} / \mathrm{L}$ & 2234 & 25 & $439.4 \pm 433.3$ \\
\hline $\mathrm{Mg} \mathrm{mmol} / \mathrm{L}$ & 1.65 & 0.29 & $0.6 \pm 0.3$ \\
\hline $\mathrm{CaXP}$ & 95 & 30 & $54.2 \pm 16.6$ \\
\hline
\end{tabular}

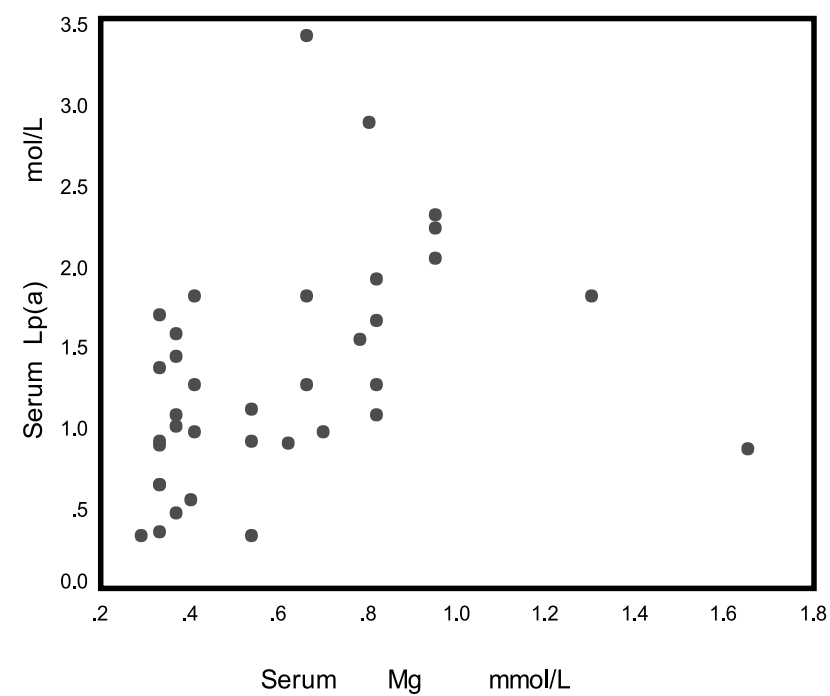

Fig. 1: Correlation of serum Magnesium with serum Lp(a) values $(\mathrm{r}=0.541, \mathrm{p}<0.01)$.

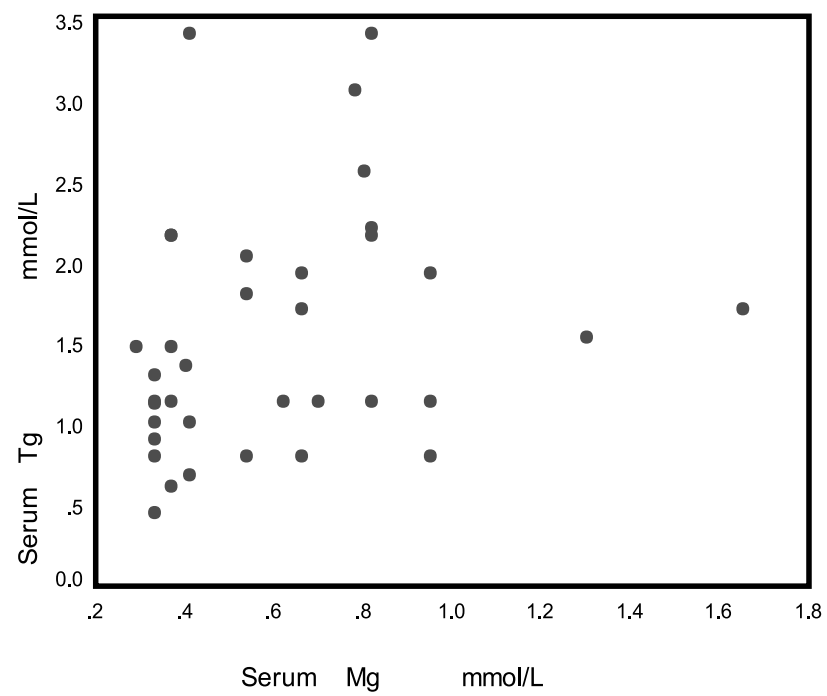

Fig. 2: Correlation of serum Magnesium with serum Triglyceride values $(\mathrm{r}=0.368, \mathrm{p}=0.014)$. kit of USA. Magnesium was measured by calorimetric method. Data are expressed as the Mean \pm SD. For correlations Spearman rho test was used and $\mathrm{P}$ value less than 0.05 was considered significant.

\section{Results}

The total patients were thirty-six $(\mathrm{F}=16 \mathrm{M}=20)$. The mean \pm SD of age of patients were $47.5 \pm 16.6$ years. The length of the time patients have been on hemodialysis were $25 \pm 24.4$ months. Table one shows patients data. In this study, there was a significant positive correlation between serum Magnesium and Lipoprotein(a) $(r=0.541, p<0.01)$ (Fig. 1). Significant positive correlation between serum Magnesium with Triglyceride level $(\mathrm{r}=0.368, \mathrm{p}=0.014)$ was observed too, (Fig. 2). There were not significant correlation between serum Magnesium with Cholesterol, HDL-C, and LDL-C ( $p>0.05)$. There were not any positive correlation between serum Calcium, iPTH and $\mathrm{Ca} \times \mathrm{P}$ product with serum lipids $(\mathrm{P}>0.05)$.

\section{Discussion}

In this study there was a positive correlation between serum $\mathrm{Mg}$ levels and serum $\mathrm{Lp}(\mathrm{a})$ also significant positive correlation of serum $\mathrm{Mg}$ levels with $\mathrm{Tg}$ was seen too, means high serum $\mathrm{Mg}$ in hemodialysis patients might be associated with some types of dyslipidemia seen in hemodialysis patients. Uremic patients undergoing hemodialysis had dyslipidemia consisting of high serum $\mathrm{Tg}$ and $\mathrm{Lp}(\mathrm{a})$ levels without cholesterol increment, while High-density lipoprotein-cholesterol has generally bean found to be decreased $(1,2,6)$. There is well documented that this lipid profile specially high serum Lp(a) and low HDL-C are highly atherogenic and are one of factors that accelerate atherosclerosis seen in these patients $(1,2,3,6,7,11)$ and needs more attention to find the etiology and treatment of this dyslipidemia. It has been suggested that $\mathrm{Mg}$ deficiency is related to alteration in lipid metabolism (11). Some animal studies showed that $\mathrm{Mg}$-deficient diet is associated with high serum $\mathrm{Tg}$ or Cholesterol levels. Rayssiguier et al. showed that in Mg-deficient non-uremic rats, no changes in serum cholesterol were found $(9,10)$. In this way Inagaki et al. found in uremic rats, Magnesium deficiency increased $\mathrm{Tg}$ levels and decreased HDL-chol levels (4). In contrast Itoh et al. utilized magnesium hydroxide $(548 \mathrm{mg} / \mathrm{dl}$ to males and $411 \mathrm{mg} / \mathrm{dl}$ for females) for 4 weeks and noted a significant improvement in blood pressure, additionally, the HDL : LDL ratio and total cholesterol improved with the magnesium treatment (5). Recently Robles et al. in a study on twenty-five hemodialysis patients found a positive significant correlation between serum magnesium levels and total cholesterol, and a nearly significant correlation between serum $\mathrm{Tg}$ and serum Triglycerids (11). In contrast to this study we found no positive correlation between seurm cholesterol with magnesium levels. We found a positive correlation between 
serum magnesium and triglyceride too. Lipoprotein(a) is an independent risk factor for atherosclerotic cardiovascular disease (CVD) in general population and dialysis patients (7). In this study we found a significant correlation between serum Magnesium and LP(a) levels. Serum Lp (a) elevation in hemodialysis patients can be due to uremia that could influence $\mathrm{Lp}$ (a) metabolism. The kidneys may play a role in $\operatorname{Lp}(\mathrm{a})$ catabolism and the end-stage renal disease might result in elevated $L p(a)$ levels $(1,6,8,12)$. Based on recent observations, showing significant correlations between serum lipoprotein (a), IL-6 and TNF- $\alpha$. Levels, it is hypothesized that an activated acute phase reaction may be the underlying cause for high levels of lipoprotein (a) found in patients receiving chronic hemodialysis $(5,11)$. Magnesium does not seem to increase lipoprotein synthesis. It may be involved in the regulation of some enzymes responsible for lipoprotein synthesis (11). While there were a trend toward an increase of triglycerid levels with increasing Magnesium levels it could be due to changes in hepatic triglycerid metabolism induced by Magnesium(11). In the meantime, further clinical study into this important aspect of hemodialysis patients is needed.

\section{References}

1. Bairaktari E, Elisaf M, Tsolos O, Siamopoulous KC. Serum LP(a) levels in patients with moderate renal failure. Nephron 1998;79:367-80.

2. De Gomez NT, Giammona AM, Touceda LA, Raimondi C. Lipid abnormalities in chronic renal failure Patients undergoing hemodialysis. Medicina (Buenos Aires) 2001;61:142-6.
3. Friedewald WT, Levy R, Fredrickson DS. Estimation of the concentration of Low-density lipoprotein cholesterol in plasma without use of the preparative ultracentrifuge. Clin Chem 1972;18:799-502.

4. Inagaki O, Shono T, Nakagawa K, Gomikawa S, Mori H, Fujita Y. Effects of magnesium deficiency on lipid metabolism in uremic rats. Nephron 1990;55:176-80.

5. Itoh $\mathrm{K}$, Kawasaki T, Nakamura $\mathrm{M}$. The effects of high oral magnesium supplementation on blood pressure, serum lipids and related variables in apparently healthy Japanese subjects. Br J Nutr 1997;78:737-50

6. Keane WF, Oda H. Lipid abnormalities in end stage renal disease Nephrol Dia Transplant 1998;13(suppl 1):45-9.

7. Quashing T, Krane V, Metzger T, Warner C. Abnormalities in Uremia lipoprotein metabolism and its impact on Cardiovascular disease. Am J Kid Dis 2001; 138(suppl 1):514-S9.

8. Rabin T, Donaski N, Finder L et al. Renal handling of human apolipoprotein (a) and its fragments in the rat. Am J Kid Dis 2001;138(3):619-30.

9. Rayssiguier Y, Gueux E, Bussiere L, Durlach J, Mazur A. Diatary Magnesium affects susceptibility of lipoproteins and tissues to per oxidation in rats. J Am College Nut 1993;12(2):133-4

10. Rayssiguier Y, Gueux E, Weiser D. Effects of magnesium deficiency on lipid metabolism in rats fed a high carbohydrate diet. J Nutr 1981;111:1877-83.

11. Robles NR, Escola JM, Albarran L, Espada R, Cruz A. Correlation of serum magnesium and serum lipid levels in hemodialysis patients. Dial Transplant 1998;27(10):644-8.

12. Zimmermann J, Herrlinger S, Pruy A, Wanner C. Mechanism of high serum lipoprotein (a) in hemo dialysis patients. JCI 1993;91:397.

Submitted March 2004

Accepted November 2004.

Hamid Nasri, M.D., Shahrekord university of Medical sciences, Hajar Medical, Educational and Therapeutic Center, Section of Hemodialysis,

Shahrekord, Iran. e-mail: hamidnasri@skums.ac.ir 